\title{
Effect of nitrogen and sulphur nutrition on yield parameters and protein composition in soybean [Glycine max (L.) Merrill].
}

\author{
A. Sharma* and S. Sharma \\ Department of Biochemistry, Punjab Agricultural University, Ludhiana-141004, INDIA \\ *Corresponding author. E-mail: anju3sep@gmail.com
}

Received: May 12, 2012 ; Revised received: August 12, 2014 ; Accepted: October 01, 2014

\begin{abstract}
Accumulation patterns of various protein fractions in seed, yield and protein quality parameters of soybean cultivar SL 525 harvested at different stages of development from plants grown under different treatments viz., nitrogen (urea @ $31.25 \mathrm{~kg} \mathrm{~N} \mathrm{ha}^{-1}$ ), sulphur (gypsum @ $20 \mathrm{~kg} \mathrm{~S} \mathrm{ha}^{-1}$ ) and combined application of nitrogen $(\mathrm{N})$ and sulphur (S) were investigated. Application of $\mathrm{S}$ alone or combined with $\mathrm{N}$ significantly increased plant height, number of seeds per pod and total seed yield. Sulphur-containing amino acids viz., methionine and cysteine increased significantly $(P \leq 0.05)$ by all the treatments in comparison to control and maximum increase of 1.3 fold was observed by urea application. The contents of different protein fractions viz., albumin, globulin and glycinin (a subfraction of globulin) increased under the effect of $\mathrm{N}$ and $\mathrm{S}$ applied alone or in combination from 30 DAP to maturity with maximum accumulation at maturity as compared to control (without N or S application). Gypsum @ $20 \mathrm{~kg} \mathrm{~S} \mathrm{ha}^{-1}$ resulted in higher accumulation of glycinin (11S) relative to $\beta$-conglycinin (7S) fraction of globulin protein in soybean seed thereby increasing 11S:7S ratio indicating improvement in soybean seed quality. The current study showed that improvement of soybean nutritional quality can be achieved by application of gypsum @ $20 \mathrm{~kg} \mathrm{~S} \mathrm{ha}^{-1}$ along with recommended $\mathrm{N}$ doses under agroclimatic conditions of Punjab.
\end{abstract}

Keywords: Nitrogen, Protein quality, Soybean, Sulphur, Yield

\section{INTRODUCTION}

Legume seeds contain high amounts of storage proteins that are classified on the basis of their solubility as water - soluble albumins, salt - soluble globulins, alcohol - soluble prolamins and acid - or alkaline - soluble glutelins (Utsumi, 1992). These seed storage proteins are synthesized in cotyledons during mid to later stages of crop development (Golombek et al., 2001). Soybean is an important commercial leguminous crop grown throughout the world and is major source of protein, oil, fiber, vitamins, minerals and other nutrients. Its seed contains $40-45 \%$ protein on dry weight basis. The most abundant seed storage proteins of soybean are salt-soluble globulins and they consist of three fractions viz., glycinin, $\beta$-conglycinin and $2 \mathrm{~S}$ proteins. Glycinin accounts for $60 \%$ of storage proteins and is relatively rich in S-containing amino acids (3-4.5\%) (Kaviani and Kharabian, 2008). It is a hexameric, 11S globulin (Mr 320-350 kDa), composed mainly of subunits A3; total A1a, A1b, A2, A4 and acidic and total basic with molecular weight 45,38 and $22 \mathrm{kDa}$, respectively. $\beta$ - conglycinin $(7 \mathrm{~S})$ is a trimeric protein $(\mathrm{Mr} 180-240 \mathrm{kDa})$ and consists of $\alpha^{\prime}, \alpha$ and $\beta$ subunits with molecular weight 76,72 and $53 \mathrm{kDa}$, respectively (Remkema et al., 2001). Subunits of $\beta$ - conglycinin contain no more than $1.1 \%$ of
S-containing amino acids (Krishnan et al., 2005) and $\beta$ -subunit of $\beta$-conglycinin is poor in quality and usually lacks limiting S-containing amino acids (Tierney et al., 1987).

The seed protein composition depends upon various environmental factors such as temperature, photoperiod and nutrition etc during seed development (Arslanoglu et al., 2011; Kumar et al., 2013). Alterations in the nutritional conditions may cause a wide range of morphological, physiological and biochemical changes by modification of genes and enzymes expression and thus protein synthesis and activity (Fabre and Planchon, 2000). Protein synthesis in soybean is reported to be highly influenced by minerals such as phosphorus, potassium, nitrogen and sulphur (Peak et al., 1997; Utsumi, et al., 2002; Mahmoodi et al., 2013). Soybean plants grown under varying levels of sodium and potassium salts influenced seed storage protein subunit composition (Kaviani et al., 2011). Sulphur as well as $\mathrm{N}$ are important nutrients required by crops for protein structure, vitamins and other structural components and also improve plant growth and yield (Marshner, 2005; Kopriva et al., 2002).

Nitrogen and $\mathrm{S}$ assimilation is well coordinated and deficiencies of one of the nutrient reduce the assimilation of other nutrient (Kopriva and Rennenberg, 2004; 
Siddiqui et al., 2008). Also, an insufficient supply of S can affect yield and quality of crop adversely (Scherer, 2001).

Soybean is considered as an alternative to rice in rice-wheat cropping system in Punjab due to its high nutritional quality and low water requirement. In a pot experiment, $\mathrm{S}$ as gypsum @ $20 \mathrm{~kg} \mathrm{ha}^{-1}$ along with urea @ $31.25 \mathrm{Kg} \mathrm{N} \mathrm{ha}^{-1}$ significantly increased nutrient uptake and seed yield (Sharma et al., 2014). In our earlier work, we have studied the effect of various sources and levels of $S$ fertilizers on storage protein accumulation in soybean crop to find out the optimum levels of $\mathrm{S}$ under the agroclimatic conditions of Punjab and observed that gypsum @ $20 \mathrm{~kg} \mathrm{~S} \mathrm{ha}^{-1}$ showed maximum seed storage proteins accumulation in soybean (Kaur, 2014). In the present investigation, gypsum @ $20 \mathrm{Kg} \mathrm{S} \mathrm{ha}^{-1}$ along with recommended dose of urea @ 31.25 Kg N ha ${ }^{-1}$ has been studied to evaluate the interactive effects of $\mathrm{N}$ and $\mathrm{S}$ application on protein quality and soybean yield.

\section{MATERIALS AND METHODS}

Study area: A field experiment was conducted at experimental fields of Pulses Section, Department of Plant Breeding and Genetics, PAU, Ludhiana during kharif season (2013) on soybean cultivar SL 525. The experiment was laid out with four replications in a randomized block design with four treatments i.e. control, urea@31.25 kg N ha ${ }^{-1}$, gypsum @ $20 \mathrm{~kg} \mathrm{~S} \mathrm{ha}^{-1}$ and urea@31.25 kg N ha ${ }^{-1}$ gypsum @ $20 \mathrm{~kg} \mathrm{~S} \mathrm{ha}^{-1}$. The experimental soil was sandy loam in texture having $\mathrm{pH} 7.7$, electrical conductivity 0.15 mmoles $\mathrm{cm}^{-1}$, organic carbon $0.51 \%$ and available nitrogen, phosphorus, potassium and sulphur contents were 0.26 $\%, 14.3 \mathrm{~kg}$ acre $^{-1}, 30 \mathrm{~kg}$ acre $^{-1}$ and $0.22 \%$ respectively. Seeds were collected at 30,40 and 50 days after podding (DAP) and maturity from each treatment. Developing and mature seeds were defatted with chloroform and methanol in $2: 1$ ratio by overnight extraction at room temperature. After centrifugation, supernatant was discarded and defatted seed flour was used for storage protein extraction and analysis.

Different protein fractions were extracted from defatted soybean seed flour based on their solubility at $25^{\circ} \mathrm{C}$ in distilled water (for albumin), $0.2 \mathrm{M}$ sodium phosphate buffer $\mathrm{pH} 8.0$ containing $3 \% \mathrm{NaCl}$ (for globulin), $70 \%$ ethanol (for prolamin) and $0.1 \mathrm{~N} \mathrm{NaOH}$ (for glutelin) following the procedure given by Pant and Tulsiani (1969). The subfractions of globulins viz., glycinins and $\beta$-conglycinins were extracted from defatted soybean flour with 5-6 volumes of $0.1 \mathrm{M}$ potassium phosphate buffer $(\mathrm{pH}$ 7.0) and further, isolated by repeated isoelectric precipitations (Basha and Beevers, 1975) where glycinins were recovered at $\mathrm{pH} 6.4$ while $\beta$-conglycinins were obtained at $\mathrm{pH} 4.8$. The protein content of various fractions was determined by the method of Lowry et al. (1951). Mature seeds were also analyzed for total soluble proteins (Lowry et al., 1951), free amino acids (Lee and Takahashi, 1966), S-containing amino acids viz., methionine (Horn et al., 1946) and cysteine (Gaitonde, 1967). Various yield parameters viz., seed yield, seeds per pod, pods per plant and plant height were determined at maturity before harvesting.

Statistical analysis: The data was analysed for the critical differences between treatments and developmental stages by applying one way analysis of variance (ANOVA) at 5\% level of significance using CPCS1 software package, developed by PAU, Ludhiana.

\section{RESULTS AND DISCUSSION}

The accumulations of albumin and globulin proteins increased significantly from 30 DAP to maturity in all the treatments (Table 1). Albumin content in seeds increased significantly $(\mathrm{P} \leq 0.05)$ in response to all the treatments as compared to control at various developmental stages and maximum increase was observed by application of urea alone @ $31.25 \mathrm{Kg} \mathrm{N}$ $\mathrm{ha}^{-1}$ at each stage of development. Accumulation of globulins showed significant $(\mathrm{P} \leq 0.05)$ increase in all the treatments and their content varied significantly among N, S and their combined application. The maximum globulin accumulation in mature seeds was observed by $\mathrm{S}$ application.

Prolamin content decreased significantly from 30 to 50 DAP and increased thereafter up to maturity in all the treatments (Table 1). Maximum accumulation of prolamins was observed by the application of gypsum alone from 30 to 50 DAP while at maturity, the maximum response was given by combined application of $\mathrm{N}$ and S. The accumulation of glutelins decreased significantly in mature seeds compared to the initial stages of development in all the treatments. Various treatments significantly increased the seed glutelin content compared to control at maturity. Prolamin and glutelin accumulation was highest in the combined application of $\mathrm{N}$ and $\mathrm{S}$ in mature seeds.

The glycinin (11S) fractions of globulin storage protein increased significantly from 30 DAP to maturity (Fig. 1) in all the treatments. Glycinin content increased by the application of $\mathrm{N}$ and $\mathrm{S}$ alone or in combination compared to control and maximum accumulation of glycinin fraction was observed at maturity in each treatment. The accumulation of $\beta$-conglycinin (7S) increased from 30 to 40 DAP in all the treatments and then decreased further up to 50 DAP (Fig. 1). The relative proportion of $\beta$-conglycinin decreased significantly $(\mathrm{P} \leq 0.05)$ by the application of $\mathrm{S}$ alone at all the developmental stages and maturity. $\mathrm{N}$ treatment alone or in combination with $S$ resulted in increased accumulation of $\beta$-conglycinin in mature seeds. $11 \mathrm{~S}: 7 \mathrm{~S}$ ratio initially decreased upto 40 DAP and then increased up to maturity in all the treatments and maximum increase was observed in S treatment.

Total soluble proteins, free amino acids content 

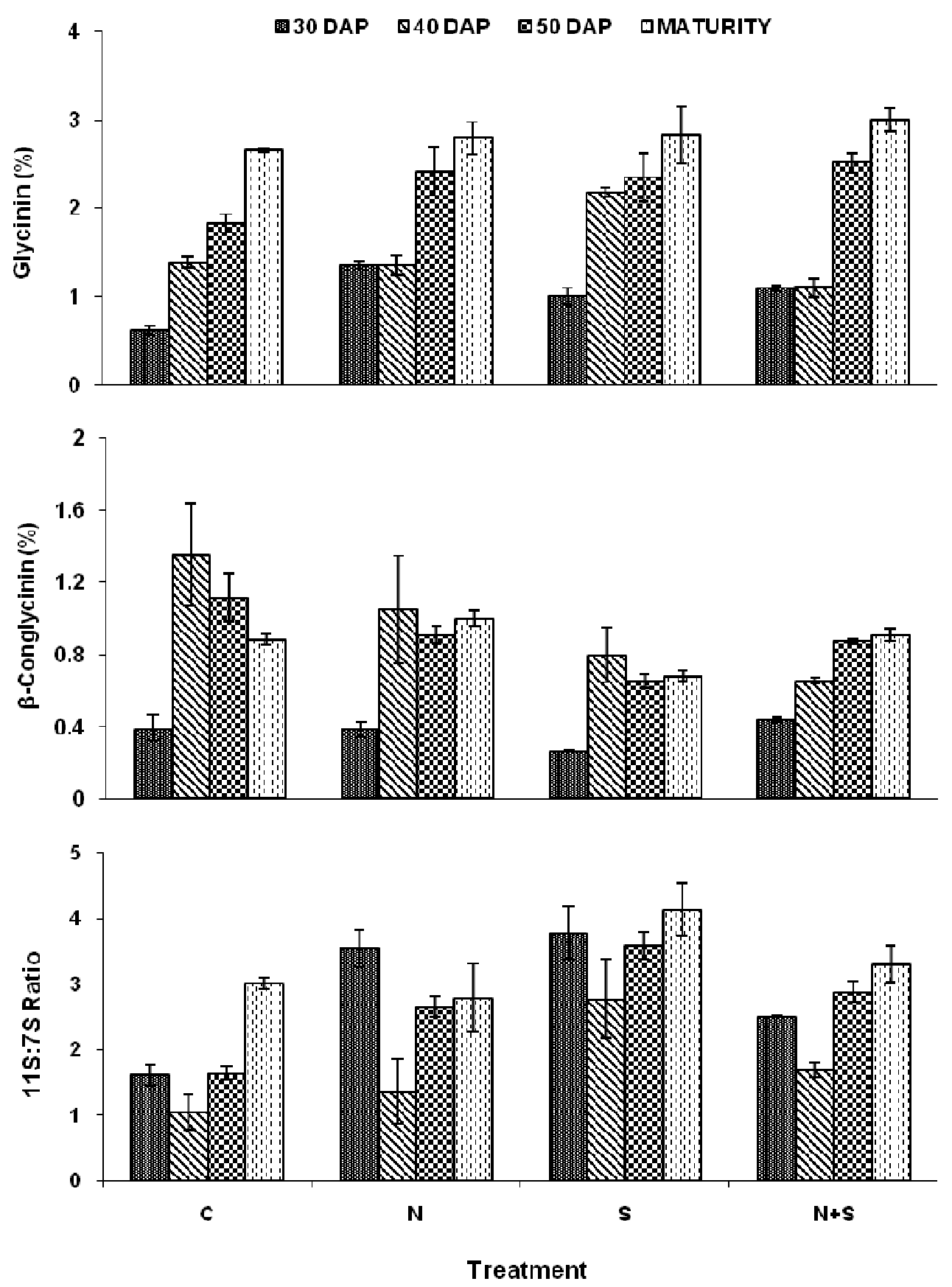

Fig. 1. Effect of nitrogen and sulphur fertilization on glycinin (11S), $\beta$-conglycinin (7S) content and 11S:7S ratio in soybean

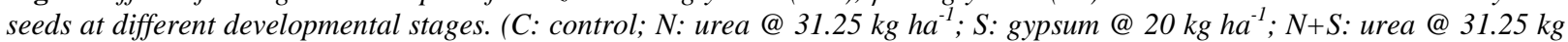
$h a^{-1}+$ gypsum@20 $\left.\mathrm{kg} \mathrm{ha}^{-1}\right)$.

increased after treatment with $\mathrm{N}$ or $\mathrm{S}$ alone or in combination but the contents varied non-significantly $(\mathrm{P} \leq 0.05)$. Methionine and cysteine content in seeds increased significantly in all the treatments in comparison to control (Table 2).

In addition to protein quality, various yield parameters determined at maturity were also affected by all fertilizer treatments (Table 3). Plant height and number of seeds per pod increased significantly by the application of $\mathrm{N}$ or $\mathrm{S}$ alone and in combination as compared to control. Seed yield increased significantly by gypsum alone @
$20 \mathrm{Kg} \mathrm{S} \mathrm{ha}^{-1}$ or by its combination with $\mathrm{N}$.

In present studies, the major proteins in soybean seeds were globulins, followed by albumins, glutelin and prolamins being the lowest. Globulins, being the major seed storage proteins in legumes, had the highest relative content in mature soybean seeds and are synthesized during seed development on polysomes, transferred via lumen, sequestered and ultimately deposited in protein bodies (Kaviani and Kharabian, 2008). Increase in albumin and globulin content in chickpea seeds by various $\mathrm{S}$ sources including single super phosphate, 


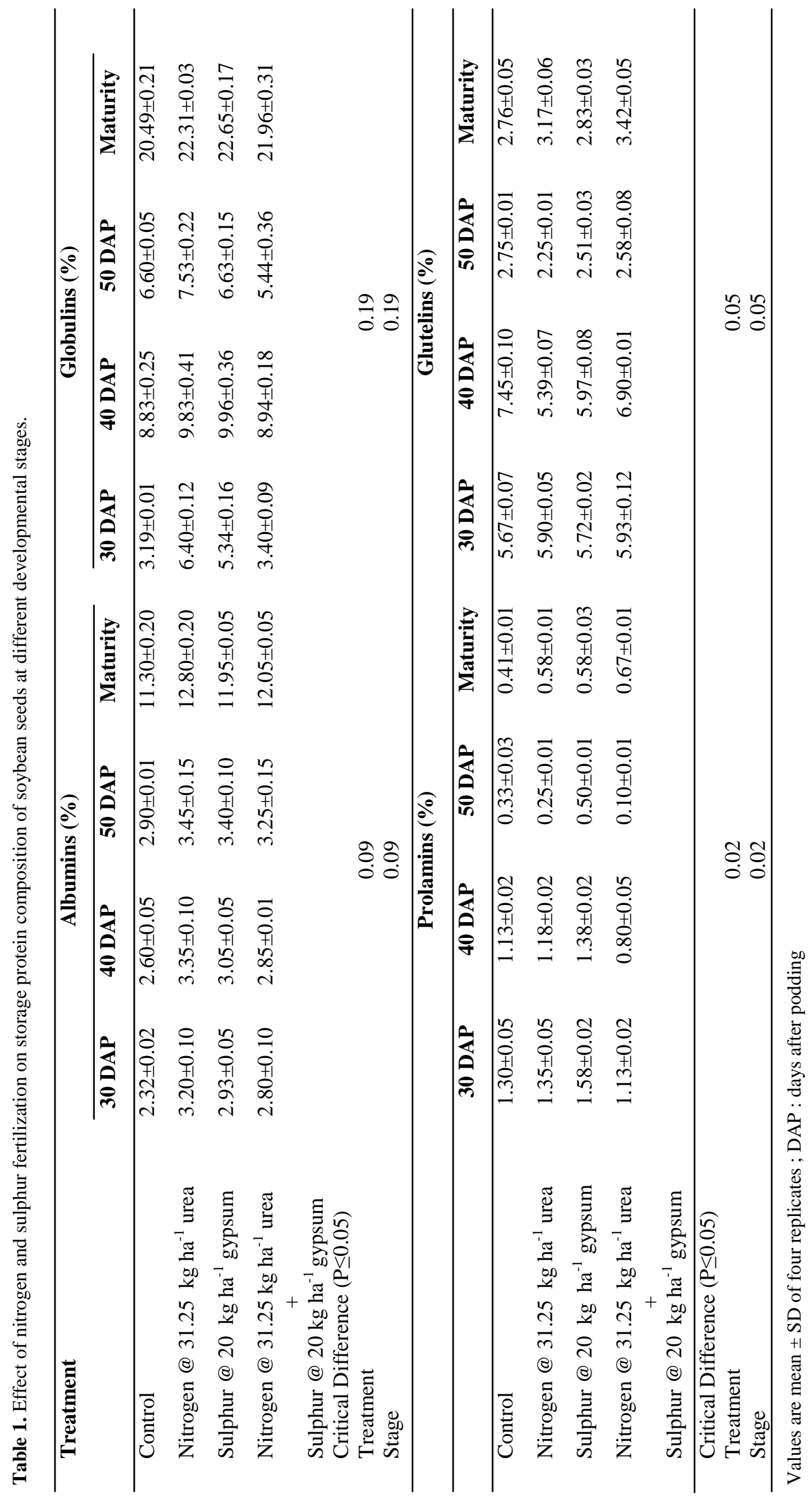


Table 2. Effect of nitrogen and sulphur fertilization on total soluble proteins, amino acids, methionine and cysteine content of mature soybean seeds.

\begin{tabular}{|c|c|c|c|c|}
\hline Treatment & $\begin{array}{c}\text { Total soluble proteins } \\
(\%)\end{array}$ & $\begin{array}{c}\text { Free amino acids } \\
(\%)\end{array}$ & $\begin{array}{c}\text { Methionine } \\
(\%)\end{array}$ & $\begin{array}{c}\text { Cysteine } \\
(\%)\end{array}$ \\
\hline Control & $21.25 \pm 0.37$ & $1.58 \pm 0.14$ & $0.57 \pm 0.04$ & $0.22 \pm 0.01$ \\
\hline Nitrogen@31.25 kg ha-1 urea & $22.13 \pm 0.81$ & $1.92 \pm 0.07$ & $0.75 \pm 0.05$ & $0.30 \pm 0.01$ \\
\hline Sulphur@ $@ 20$ kg ha-1 gypsum & $22.66 \pm 0.65$ & $1.88 \pm 0.25$ & $0.73 \pm 0.09$ & $0.27 \pm 0.01$ \\
\hline $\begin{array}{l}\text { Nitrogen @ } 31.25 \text { kg ha-1 urea } \\
+ \\
\text { Sulphur @ } 20 \text { kg ha-1 gypsum }\end{array}$ & $22.88 \pm 0.81$ & $1.92 \pm 0.01$ & $0.70 \pm 0.05$ & $0.26 \pm 0.01$ \\
\hline Critical Difference $(\mathrm{P} \leq 0.05)$ & NS & NS & 0.12 & 0.02 \\
\hline
\end{tabular}

Values are mean \pm SD of four replicates, NS: Non-significant.

Table 3. Effect of nitrogen and sulphur fertilization on yield parameters of soybean.

\begin{tabular}{lcccc}
\hline Treatment & $\begin{array}{c}\text { Seed Yield } \\
(\mathbf{k g} / \mathbf{p l o t})\end{array}$ & Pods/plant & Seeds/pod & $\begin{array}{c}\text { Plant Height } \\
(\mathbf{c m})\end{array}$ \\
\hline Control & $1.27 \pm 0.14$ & $103.33 \pm 5.03$ & $2.05 \pm 0.09$ & $67.66 \pm 2.51$ \\
Nitrogen @ 31.25 kg ha-1 urea & $1.30 \pm 0.08$ & $82.67 \pm 4.50$ & $2.15 \pm 0.12$ & $71.67 \pm 0.57$ \\
Sulphur @ 20 kg ha-1 gypsum & $1.65 \pm 0.10$ & $89.00 \pm 8.00$ & $2.50 \pm 0.06$ & $73.67 \pm 1.52$ \\
Nitrogen @ 31.25 kg ha-1 urea & $1.62 \pm 0.07$ & $106.33 \pm 14.46$ & $2.23 \pm 0.07$ & $75.33 \pm 1.15$ \\
+ & & & & \\
Sulphur @ 20 kg ha-1 gypsum & 0.20 & 16.82 & 0.16 & 3.03 \\
Critical Difference (P $\leq 0.05)$ & & & &
\end{tabular}

Values are mean $\pm \mathrm{SD}$ of four replicates.

gypsum and elemental $\mathrm{S}$ at all developmental stages (Ghalotra et al., 2007), by $\mathrm{N}$ and $\mathrm{S}$ in chickpea (Singh and Matta, 2005) and mungbean (Kumar et al., 2013) have been reported whereas seed globulin decreased in lupin seeds due to $S$ deficiency (Gillespie et al., 1978). In the present studies, the increase in globulin and albumin contents in soybean seeds with $\mathrm{N}$ and $\mathrm{S}$ supply alone or in combination suggested that supply of various minerals can improve the storage protein fractions in soybean.

There was higher accumulation of $11 \mathrm{~S}$ fractions at maturity with $\mathrm{N}$ and $\mathrm{S}$ treatments as glycinin proteins are reported to reach maximum transcription level at 70-80 DAF (Nielsen et al., 1989). There was decreased accumulation of $\beta$-conglycinin due to $\mathrm{N}$ and $\mathrm{S}$ alone or in combination except that $\mathrm{N}$ application increased its content at maturity. Peak et al. (1997) have shown that nitrogen source has a profound effect on the relative amounts of $\beta$-subunit of $\beta$-conglycinin and that the accumulation of $\beta$-subunit is controlled by $\mathrm{N}$ availability. Eliminating or reducing the $\beta$-subunit has been suggested as one method of improving the quality of soybean proteins (Wilson, 1987). Accumulation of S-poor $\beta$-subunit of $\beta$-conglycinin was promoted by excess application of $\mathrm{N}$ or by $\mathrm{S}$ deficiency while the application of $\mathrm{S}$ fertilizers increased glycinin synthesis (Krishnan, et al.,, 2000; Awazuhara et al.,, 2002 and Krishnan, et al., 2005). The S-poor $\beta$-subunit of $\beta$ conglycinin is more strongly expressed under nitrogen nutritional conditions that promote $7 \mathrm{~S}$ protein, whereas S-containing subunits are influenced less or not at all, thereby deteriorating the $11 \mathrm{~S} / 7 \mathrm{~S}$ ratio. $\beta$-subunit of $\beta$-conglycinin demonstrated plasticity in response to $S$ availability (Tabe et al.,, 2002; Hagan et al., 2003) which modulated the expression of transcripts and genetic developmental program (Rolletschek et al., 2005).

Availability of S-amino acids in the developing seeds determined which storage protein subunits were synthesized from the extra N. The increase in contents of S-containing amino acids by $\mathrm{N}$ and $\mathrm{S}$ alone or in combination in present studies suggest improvement of seed storage protein quality. Sulphur fertilization increased cysteine and glutathione content of leaves while $\mathrm{N}$ fertilization had no significant influence (Bloem et al., 2010) at all the developmental stages in garlic.

In the present studies, plant height, seeds per pod and seed yield improved by $\mathrm{S}$ alone or combined with $\mathrm{N}$ whereas $\mathrm{N}$ alone decreased number of pods per plant thus showing non-significant $(\mathrm{P} \leq 0.05)$ variation in seed yield as compared to control. Sulphur application @ $40 \mathrm{~kg} \mathrm{ha}^{-1}$ enhanced the plant height, branches, pod/ plant and $1000 \mathrm{~g}$ weight in green gram (Sharma and Singh, 1997), black gram (Singh and Aggarwal, 1998) and soybean (Ganeshamurthy and Reddy, 2000). The improved growth and physiological attributes appear to be mainly responsible for the observed parallel 
increase in the various yield characteristics studied. Nitrogen and $\mathrm{S}$ assimilation was enhanced due to fertilizer treatment that can be correlated to yield.

\section{Conclusion}

From the present studies, it was concluded that gypsum@20 kg S ha ${ }^{-1}$ alone or in combination with recommended doses of nitrogen for soybean improved the total storage protein, glycinin fraction of globulin, S-containing amino acids and seed yield in soybean under agro-climatic conditions of Punjab whereas the content of S-deficient $\beta$-conglycinin fraction decreased thus improving $11 \mathrm{~S}: 7 \mathrm{~S}$ ratio indicating improvement in protein quality of soybean. Hence, S as gypsum @20 $\mathrm{kg} \mathrm{ha}^{-1}$ along with urea @ $31.25 \mathrm{~kg} \mathrm{~N} \mathrm{ha}^{-1}$ can be used to improve yield and storage protein quality of soybean under local climatic conditions.

\section{REFERENCES}

Arslanoglu, F., Aytac, S. and Oner, E. K. (2011). Effect of genotype and environment interaction on oil and protein content of soybean (Glycine max (L.) Merrill) seed. African Journal of Biotechnology, 10: 1840918417.

Awazuhara, M., Kim, H. and Hayashi, H. (2002). Composition of seed storage proteins changed by glutathione treatment of soybean. Bioscience Biotechnology and Biochemistry, 66: 1751-1754.

Basha, S. M. M. and Beevers, L. (1975). The development of proteolytic activity and protein degradation during germination of Pisum sativum (L.). Planta, 124: 77-87.

Bloem, E., Haneklaus, S. and Schnug, E. (2010). Influence of fertilizer practices on S-containing metabolites in garlic (Allium sativum L.) under field conditions. Journal of Agriculture and Food Chemistry, 58(19): 10690-10696.

Fabre, F. and Planchon, C. (2000). Nitrogen nutrition, yield and protein content in soybean. Plant Science, 152: 5158.

Gaitnode, M. K. (1967). A spectrophotometric method for the direct determination of cysteine in the presence of other naturally occurring amino acids. Biochemical Journal, 104: 627-633.

Ganeshamurthy, A. N. and Sammi, R. K. (2000). Effect of integrated use of farmyard manure and sulphur in a soyabean and wheat cropping systems on nodulation dry matter production and chlorophyll content of soyabean on swell-shrink soil in central India. Journal of Agronomy and Crop Science, 185: 91-97.

Ghalotra, J., Sital, J. S. and Batta, S. K. (2007). Effect of sulfur nutrition on biochemical parameters in developing chickpea (Cicer arietnum L.) seeds. Indian Journal of Agricultural Biochemistry, 20: 59-62.

Gillespie, J. M., Blagrove, R. J. and Randall, P. J. (1978). Effect of sulfur supply on seed globulins composition of various species of lupin. Australian Journal of Plant Physiology, 5: 641-650.

Golombek, S., Rolletschek, H., Wobus, U. and Weber, H. (2001). Control of storage protein accumulation during legume seed development. Journal of Plant Physiology, 158: 457-464.

Hagan, N., Tabe, M. and Higgins, T. J. V. (2003). Modifying the amino acid composition of grains using gene technology. Plant biotechnology 2002 and beyond, Kluwer Academic Publishers, Dordrecht, The Netherlands, pp 305-308.

Horn, M. J., Jones, B. and Blum, A. E. (1946). Colorimetric determination of methionine in proteins and foods. Journal of Biological Chemistry, 166: 313-320.

Kaur, G. (2014). Effect of sulphur supply on sulphur and nitrogen assimilating enzymes and protein quality in developing soybean (Glycine max (L.) Merrill) seeds. $\mathrm{Ph}$ D Thesis.

Kaviani, B. and Kharabian, A. (2008). Improvement of the nutritional value of soybean [Glycine $\max (\mathrm{L})$ Merr.] seed with alteration in protein subunits of glycinin (11S Globulin) and $\beta$-conglycinin (7S Globulin). Turkish Journal of Biology, 32: 91-97.

Kaviani, B., Pourkhalili, S. T., Sajedi, R. H. and Mosadegh, B. (2011). Salt treatment can change composition of glycinin and $\beta$-conglycinin proteins in soybean seed. Plant Omics Journal, 4(4): 228-235.

Kopriva, S. and Rennenberg, H. (2004). Control of sulphate assimilation and glutathione synthesis: interaction with $\mathrm{N}$ and $\mathrm{C}$ metabolism. Journal of Experimental Botany, 55(104): 1831-1842.

Kopriva, S., Suter, M., Von, B. P., Hesse, H., Krähenbühl, U., Rennenberg, H. and Brunold, C. (2002). Interaction of sulfate assimilation with carbon and nitrogen metabolism in Lemna minor. Plant Physiology, 130: 1406-1413.

Krishnan, H. B., Bennet, J. O., Kim, W. S., Krishnan, A. H. and Mawhinney, T. P. (2005). Nitrogen lowers the sulphur amino acid content of soybean [Glycine max (L.) Merril] by regulating the accumulation of BowmanBirk Protease inhibitor. Journal of Agricultural and Food Chemistry, 53: 6347-6354.

Krishnan, H. B., Jiang, G., Krishnan, A. H. and Wiebold, W. J. (2000). Seed storage protein composition of non-noduling soybean [Glycine $\max (\mathrm{L}$.$) Merr] and its$ influence on protein quality. Plant Science, 157: 191199.

Kumar, A., Sharma, S., Sital, J. S. and Singh, S. (2013). Effect of sulphur and nitrogen nutrition on storage protein quality in mungbean [Vigna radiata (L.) Wilczek] seeds. Indian Journal of Agricultural Biochemistry, 26: 86-91.

Lee, Y. P. and Takahashi, T. (1966). An improved colorimetric determination of amino acids with use of ninhydrin. Analytical Biochemistry, 14: 71-77.

Lowry, O. H., Rosbrough, N. J., Farr, A. L. and Randall, R. J. (1951). Protein measurement with the folin phenol reagent. Journal of Biological Chemistry, 193: 265275 .

Mahmoodi, B., Mosavi, A. A., Daliri, M. S. and Namdari, M. (2013). The evaluation of different values of phosphorus and sulfur application in yield, yield components and seed quality characteristics of soybean (Glycine Max L.). Advances in Environmental Biology, 7(1): 170176.

Marshner, H. (2005) Mineral nutrition of higher plants. Second edition. Elsevier Academic Press, London, UK.

Nielson, N. C., Dickinson, C. D., Cho, T. J., Thanh, V. H., Scallon, B. J., Fischer, R. L., Sims, T. L., Drews, G. N. and Goldberg, R. B. (1989). Characterization of the glycinin family in soybean. Plant Cell, 1: 311-328.

Pant, R. and Tulsiani, R. P. (1969). Solubility amino acid 
composition and biological evaluation for protein isolation from leguminous seed. Journal of Agricultural and Food Chemistry, 17: 361-366.

Peak, N. C., Imsande, J. and Shoemaker, R. C. (1997). Nutritional control of soybean seed storage protein. Crop Science, 37: 498-503.

Remkema, J. M. S., Knabben, J. H. M. and Vliet, T. V. (2001). Gel formation by $\beta$-conglycinin and glycinin and their mixtures. Food Hydrocolloids, 15(4-6): 407415.

Rolletschek, H., Radchuk, R., Klukas, C., Schreiber, F., Wobus, U. and Borisjuk, L. (2005). Evidence of a key role for photosynthetic oxygen release in oil storage in developing soybean seeds. New Phytologist, 167: 777-886.

Scherer, H. W. (2001). Sulphur in crop production - invited paper. European Journal of Agronomy, 14: 81-111.

Sharma, A., Sharma, S. and Gill, P. P. S. (2014). Influence of nitrogen and sulphur application on nutrient uptake, protein content and yield parameters of soybean. Indian Journal of Plant Sciences, 3(2): 31-34.

Sharma, M.P. and Singh, R. (1997). Effect of phosphorus and sulphur on greengram (Phaseolus radiatus). Indian Journal of Agronomy, 42: 650-652.

Siddiqui, M.H., Mohammad, F., Khan, M.N. and Khan, M. M. A. (2008). Cumulative effect of soil and foliar application of nitrogen, phosphorus, and sulfur on growth, physico-biochemical parameters, yield attributes, and fatty acid composition in oil of erucic acid-free rapeseed-mustard genotypes. Journal of Plant Nutrition, 31: 1284-1298.

Singh, R. and Matta, N. K. (2005). Chickpea seed proteins as affected by mineral supply levels. Journal of Plant Biochemistry and Biotechnology, 14: 77-79.

Singh, Y. P. and Aggarwal, R. L. (1998). Effect of sulphur and levels on yield, nutrient uptake and quality of black gram (Phaseolus mungo). Indian Journal of Agronomy, 43: 448-452.

Tabe, L., Hagan, N. and Higgins, T. J. V. (2002). Plasticity of seed protein composition in response to nitrogen and sulphur availability. Current Opinion in Plant Biology, 5: 212-217.

Tierney, M. L., Bary, E. A. and Allen, R. D. (1987). Isolation and characterization of a genomic clone encoding the subunit of Beta-conglycinin. Planta, 172: 356-363.

Utsumi, S. (1992). Plant food protein engineering. Advances in Food and Nutrition Research, 36: 89-208.

Utsumi, S., Maruyama, N. and Satoh, R. (2002). Structure function relation of soybean protein revealed by using recombinant systems. Enzyme and Microbial Technology, 30: 284-288.

Wilson, R.F. (1987). Seed metabolism. Soybeans: Improvement, Production and Uses, American Society of Agronomy: Madison, Wisconsin, pp 643-686. 